\title{
Defining harm: The harm principle and religious rights in South Africa
}

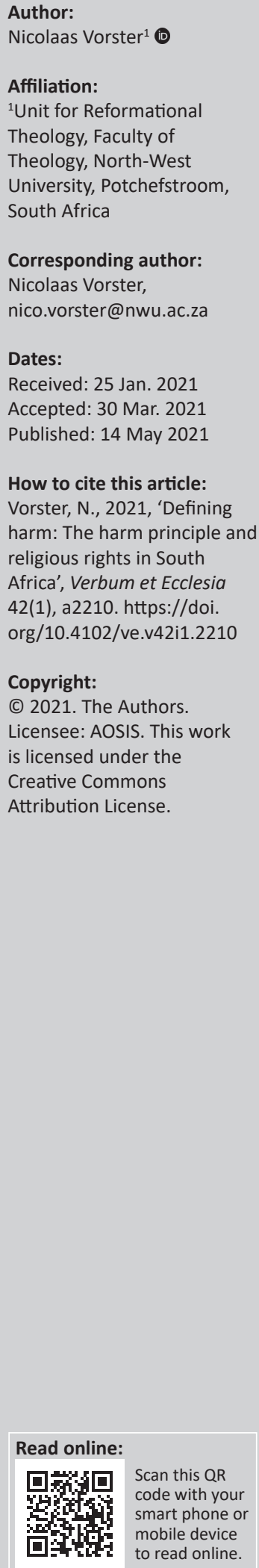

This article asks whether the harm principle, as originally formulated by John Mill and applied in religious rights discourse, is sufficiently coherent to be used as a criterion for the limitation or protection of religious rights. The philosophical and legal plausibility of the concept is discussed against the setting of the South African Cultural, Religious and Linguistic (CRL) Commission's recent recommendations with regard to regulation of religion. In effect, the Commission employed the harm principle to advocate a general limitation of religious rights. The main thesis presented is that the harm principle is fluid and open to ambiguity. Although harm is always a consideration in rights discourse, the concept does not lend itself to categorical use or as a trustworthy standard for general limitations on rights. Moreover, the 1996 Constitution's embrace of dignity as Grundnorm, concomitant with the incorporation of the notion of crimen injuria in South African common law, makes it potentially easy for the state to limit freedom of expression and intervene in religious matters under the guise of the so-called dignitary harms.

Intradisciplinary and/or interdisciplinary implications: This study brings into dialogue religion, legal philosophy and human rights discourse against the background of the debate in South Africa about state regulation of religion. It calls for a re-evaluation of the harm principle in legal and philosophical discourse and for the development of alternative conceptual tools in human rights discourse to assist in judgements pertaining to the limitation of religious rights.

Keywords: religious freedom; harm principle; Cultural, Religious and Linguistic Rights Commission; South Africa; religious rights.

\section{Introduction}

In his much-discussed essay entitled On Liberty (1863), John Stuart Mill (1806-1873) articulates the harm principle as follows:

[T] he only purpose for which power can be rightfully exercised over any member of a civilised society, against his will, is to prevent harm to others... The only part of the conduct of anyone, for which he is answerable to society, is that which concerns others. In the part which merely concerns himself, his independence is, of right absolute. Over himself, over his mind and body, the individual is sovereign. (pp. 22-23)

Mill contends that the intrinsic nature of an act, or the intention behind an act, can never serve, on its own, as a sufficient reason for prohibition or criminal sanction. To justify prohibition, a wrong act must be connected to bad effects on others (Ripstein 2006:219). In this way, Mill attempted to protect individual autonomy and curb the propensity of the state to unduly criminalise human conduct. The harm principle was refined in the 20th century by legal theorists such as Herbert Hart (1907-1922), Joseph Raz (1939-) and Joel Feinberg (1926-2004). As a result, the principle has developed into two versions. The ex-post version holds that coercion is only permissible when it in fact prevents or minimises harm, whilst the ex-ante position posits that coercion is justified only if it prevents or reduces risk (Holtug 2002:359). By using risk as a determining factor, the ex-ante position gives a wider ambit to the harm principle than the ex-post version.

To this day, the harm principle occupies a prominent place in criminal law theories and liberal political theory (Dripps 1998:3). It has been used in human rights jurisprudence to determine the conditions under which the state is justified to coerce persons in order to prevent harm to others (Du Plessis 2016:349; see Holtug 2002:360; see Barclay 2020:346). Moreover, the principle has been formally used in court cases pertaining to the protection or limitation of religious freedom (Barclay 2020:334; Du Plessis 2016:349).

This article asks whether the harm principle is sufficiently consistent and coherent to serve as a criterion for protecting or limiting religious rights. I probe the question against the background of 
the debate in South Africa about state regulation of religion, specifically the recent proposal of the South African Commission of Religious Rights that regulatory mechanisms need to be devised in order to prevent harm-doing in the name of religion. The main thesis presented is that the harm principle, even when qualified by mediating maxims, tends to collapse on itself because it is a non-categorical and fluid concept. It is, therefore, not suitable to act as a stand-alone general rule in decisions about the limitation of rights.

In the following, the first section indicates how the harm principle was employed and interpreted by different parties in the debate about the regulation of religion in South Africa. The second section presents three arguments to substantiate the main thesis that the harm principle tends to break down when applied as a general principle in rights limitation jurisprudence:

1. The harm principle is fluid and broad, resulting in a proliferation of rival claims.

2. It is by nature non-categorical. This debilitates its use as a generally applicable principle for determining whether rights should be protected or limited.

3. Within the South African context, the harm principle is open to abuse of state power. The 1996 Constitution's embrace of dignity as a ground value, concomitant with the incorporation of the notion of crimen injuria in South African common law, makes it potentially easy for the state to limit freedom of expression and intervene in religious matters under the guise of the so-called dignitary harms.

\section{The harm principle and the regulation of religion debate in South Africa}

The debate in South Africa about the regulation of religion developed against the background of a rise in disturbing and odd religious practices such as pastors forcing their congregants to eat grass and snakes and drink petrol or pay huge sums of money for miracle healings (see Banda 2019:4). In response, the South African Commission for the Promotion and Protection of Cultural, Religious and Linguistic Rights (CRL Rights Commission) decided to embark on public hearings on the commercialisation of religion in South Africa (CRL Report 2017:6). In its final report, the Commission listed a number of practices that they considered to be highly problematic, namely, the lack of sound governance structures and financial mismanagement, the running of churches as profit-making businesses, illegal advertising, deliberate exploitation of the poor by soliciting, gifts, tithes and offerings, the hero worship of church leaders, indoctrination of members to engage in antisocial practices such as withholding their children from schools or refusing the use of banking facilities, preachers making diagnoses and prognoses in health matters and the uncontrolled movement of cash in and out of the country (CRL Report 2017:2, 32-33). As a remedy, the report recommended an amendment to the 2002 Act on the Promotion and Protection of Cultural, Religious and Linguistic Rights. This would compel religions to register as non-profit organisations, a non-profit company or a public benefit organisation.
It would also create statutory bodies to issue operating licences to practitioners and religious institutions and assist churches in self-regulation (CRL Report 2017:39). The statutory bodies would have far-reaching powers with regard to the internal affairs of religious institutions, such as making recommendations to the Commission regarding registering or de-registering religious institutions, intervening in disputes, overseeing the soundness of governance structures and acting as spiritual guides to member institutions (CRL Report2017:44-47). Unsurprisingly, religious groups, civil society actors and various legal scholars rejected the recommendations and accused the Commission of abusing its power to bring religions under state control.

Of direct concern for this article are the issues raised with regard to harm and the application of the harm principle. The preliminary CRL report (2016) used the harm principle as a premise for determining the religious institutions that would receive licences to operate:

The religion should have a set of rules and practises [sic] that orders the lives of followers in a particular and specific way that benefit $[s]$ the followers. No practise [sic] should be allowed if deemed to have a harmful effect on physical or mental wellbeing of its followers, or if deemed exploitive of those who practise it. (p. 33 par. 18.1)

Even though the Commission's final report omitted the preliminary report's explicit references to the harm principle, the Commission's main argument remained the same, namely, that harmful and abusive practices in the religious sphere justified stricter regulation of religious freedom and narrower interpretation of what constitutes legitimate religion (CRL Report 2017:29-30). The final report also casted doubt on whether existing criminal and civil laws were adequately able to regulate the harm done by extremist religious groups and leaders, as many loopholes exist in present-day legislation (see FOR SA \& SACRRF 2017:24 par. 46 and CRL Report 2017:35). In a subsequent article in the Mail and Guardian, legal scholar Lerato Maviya (2018:29 March) supported the Commission's stance and claimed that some forms of objective psychological and physical harm caused by religions were not punishable under contemporary South African criminal law. She cited the example of children forced to participate in religious practices and punished if they did not. Maviya (2018) called for the establishment of a special investigative unit under the Commission to 'investigate religious practices that may not amount to a crime but nevertheless have the effect of objectively harming church members'.

In contrast, opponents of state regulation claimed that almost all harms cited by the Commission could be adequately dealt with under civil and criminal law (CLEFA 2017:3; IRRF 2017:6; SACRRF 2017:24). On a theoretical level, the South African Council for the Protection and Promotion of Religious Rights (SACRRF) and Freedom of Religion South Africa (FORSA) (2017) questioned the use of the harm principle as a benchmark for determining the groups to be excluded from the Commission's definition of religion: 
[E]xperience has shown that the concept of 'harmful' is extremely subjective and fluid (changing over time), with the result that it is open to multiple interpretations and even abuse. As a result, the question of whether or not the beliefs and practices of a particular religion (or religious institution) are deemed harmful (and whether or not they should be recognised as a religion in the first place) is entirely dependent on the subjective religious convictions and beliefs of the members of the Peer Review Council. (p. 46)

A state of affairs had, in other words, developed where proponents of state regulation of religion utilised the harm principle to justify limitations on religious freedom, whilst the most diverse and representative bodies of religions in South Africa (Freedom of Religion South Africa [FOR SA] and South African Council for the Protection and Promotion of Religious Rights [SACRRF]) resisted state intrusion by inter alia questioning the use of the harm principle in law. This is quite surprising, as the harm principle was originally devised by Mill to protect individual autonomy against state interference, rather than providing the state with a means to intrude in the private sphere and to coerce individuals.

The CRL Rights Commission insisted that the recommended regulation measures did not amount to state regulation of religion, as the Commission was (and still is) a Chapter 9 mechanism of the Constitution. However, the SACRRF and FORSA (2017:5) response rightly points out that the measures constitute a 'form of state regulation as a functionary of the State will have the ultimate power to decide on whether a religious institution may or may not be registered'. Quite surprisingly, the CRL Rights Commission argued further that the proposed regulatory measures did not constitute limitations on religious freedom. However, the mere fact that the Commission recommended that existing law should be amended in order to compel religious institutions to register as institutions, licence practitioners, associate with an umbrella organisation and explain themselves to statutory bodies with regard to matters of governance constituted a state limitation on the autonomy of religious institutions and, therefore, the right to freedom of religion.

We may, indeed, be confronted here with a classic case of opposing parties utilising a principle if and when it suits their ends. But we also need to entertain the possibility that the harm principle is open to abuse and does not provide a sufficient means to protect individual autonomy and religious rights. In the following section, I will explain why I believe the latter to be true.

\section{The inadequacy of the harm principle in limiting religious rights}

On face value, the term 'harm' seems to embody a rather innocent and straightforward idea. We intuitively think of laws as a means to prevent harm, and we can hardly conceive of a public or legal debate where the prevention of harm and offense is not a key issue. In reality, though, the meaning of 'harm' is open and fluid. Usually, we speak of harms that refer to measurable things such as physical injury, economic losses or rights limitations. But then second-order questions arise: what is the reach of the harm principle? What about subjective harms that cause moral offense, self-inflicted harms such as self-mutilation and addiction, dignitary harms that cause emotional distress or affront to an individual's or group's sense of self-worth and third-party harms that often emanate from the unintended results of trade-offs between parties?

Another complicating factor is the nature of society. Societies are more than aggregates of individuals; they also consist of cultural and ethnic groups, social organisations, trade unions, political formations, companies, interest groups and so forth, all of whom may fall victim to direct and indirect kinds of harm, offense and damages, which may trickle down to the individual level. Lastly, some harms are caused by economic competition and political contestation which are not avoidable. Where does one draw the line between harms caused by fair contests and unfair forms of discrimination?

Clearly, the semantic range of the term 'harm' is enormous so much so that one has to ask whether the harm principle can indeed be used as a trustworthy tool when it comes to the extension or limitation of rights. In fact, the Supreme Court of Canada dismissed the principle as 'too ambiguous' to use in a 'precise manner' (Du Plessis 2016:352). To determine harm and the consequences of possible coercive state action, one must unavoidably engage case-specific considerations, causal reasoning, complicated processes of interest balancing and estimations of possible outcomes. Each harm must be proven based on its effects, each rule must be justified in terms of the harm it prevents and any envisaged form of coercion should not create more harm than it prevents. The sheer scope of considerations and the fluid contents of harm make the application of the harm principle extremely difficult and general rule applications almost impossible.

What makes harm so elusive is the risk that contextual considerations, causal arguments and measurements of consequences can always be presented and construed by proponents of a certain action, or the antagonists of the exercise of a specific right, in a manner that points to some plausible kind of harm (see Dripps 1998:8). A case in point is the CRL report's (2017:19) reference to the paying of tithes or offerings during worship services as a form of harmful exploitation. The paying of tithes to support the ministering of the gospel has long been a custom in the Christian tradition, and many Christians consider it as a biblical principle. However, the CRL Commission gave a harm-based 'twist' to the practice, describing it as a form of exploitation and presenting it as a reason to support the regulation of religion. To outsiders, the Commission's argument may sound plausible and entirely reasonable but, in reality, the practice is mostly innocuous.

Another difficulty is that our understanding of the chains of harm tends to extend as modern natural and social scientific knowledge grows (Dripps 1998:9). Practices that have not been considered to be harmful in the past, such as smoking in public, are now considered by many as harmful behaviour. The ever-extending list of harms complicates the interpretation 
of the concept even further, and increases the risk that a liberal principle can be used for non-liberal ends. Richard Epstein (1995) succinctly describes the illiberal trajectory of the harm principle:

$[D]$ uring the nineteenth century, the harm principle served as a bulwark of liberty and a limit on the scope of government power. By degrees, however, it has been transformed towards the end of the twentieth century into an engine of social control that is said to justify major government intervention in all its manifestations. (p. 371)

In fairness, legal theorists and courts have devised a number of mediating maxims to limit the scope of harm arguments and to balance competing interests. Joel Feinberg (1986:115), for example, utilised the maxims of volenti non fit injuria and de minimis non curat legis to narrow the ambit of harm. The first maxim holds that a person cannot bring a claim against another party if he or she has consented to place themselves in a position where harm can result, whilst the latter holds that courts do not consider trivial matters. Dripps (1998:9), however, indicates that Feinberg's mediating maxims do not resolve the problem of scope, because courts disagree about what constitutes trivial (de minimis) matters, especially when it comes to vices that cause widespread moral offense, for instance, issues such as blasphemy. The issue of consent is also thorny, as people do not always act rationally when they give their consent. Here, we could cite the example of congregants who willingly subjected themselves to grass eating and petrol drinking. Theoretically, they acted voluntarily but, in reality, they were manipulated and indoctrinated by a person who presented himself as a prophet of God. Consent does not always ensure non-coercion. Other common law theorists have attempted to undercut the scope of harm arguments by developing the notion of damnum absque iniuria which distinguishes between subjective interests and interests that require legal protection (Epstein 1995:382). But the question remains: what is the dividing line between the two?

Because of its fluidity, the harm principle cannot, in my view, be used as a categorical principle. In fact, the Supreme Court of Canada rejected the use of the harm principle as a 'fundamental principle of justice', although it affirmed the importance of avoiding harm ( $R$ v. Malmo-Levine 2003, SCC 74, par 111). This is not surprising: what amounts to harm and leads to harmful practices in one specific context may be harmless in a different set of circumstances. We rarely find ourselves in situations where a simple distinction between harm and non-harm exists (Barclay 2020:331). In most cases, trade-offs are needed. As was illustrated by the actions of the CRL Commission, a simplistic and categorical application of the harm principle may lead to abuse. Instead of dealing with abusive religious practices on a case-by-case basis in the light of existing laws, the CRL Commission decided to use the harm argument as a general justification to limit religious rights. The abusive actions of some were seen as sufficient reason to justify a general limitation on religious freedom through the establishment of statutory regulatory mechanisms that prescribe to a wide range of denominations how they should structure their own governance. The end result was that a maxim initially devised to curb undue regulation and protect individual autonomy, which became a means to justify the extensive regulation of all religions in South Africa.

We may say that the problem, in this case, does not lie with the harm principle itself, but with its implementation. This is indeed true. One cannot simply discard a concept because it is complicated or requires a balancing of interests. Many other accepted legal principles exhibit the same features. The conceptual point, however, is that the harm principle by its very nature constitutes a case-specific heuristic tool. In other words, harm and risk assessment may assist us in the process of decision-making, but the mere presence of harm in a specific case does not justify general, across-the-board limitations on fundamental rights. Du Plessis (2016) rightly notes that:

$[T]$ he proposal of a principle should always be accompanied by the justification as to why it is legally significant and why it should be the sole method of determining the limitation of a right. (p. 16)

She proceeds to state that the isolated use of the harm principle in religious rights discourse to warrant state intervention is 'completely unjustified'. The South African Law Commission's review of the 1959 Witchcraft Suppression Act represents, in my view, a good example of a case where the harm principle has been used in a responsible manner as a situation-specific heuristic lens and not as a general rule for limitation of rights. Instead of describing witchcraft per se as a harmful practice, the Commission opted to distinguish between witchcraft as religious belief and harmful witchcraft practices which need to be regulated (South African Law Reform Commission 2014). In doing so, the Commission resisted the temptation to present the harmful acts of some as sufficient reason to limit the religious rights of all or to discriminate at random against a specific religious belief.

Lastly, I submit that the harm principle is particularly open to abuse within the South African context because of the Constitution's emphasis on human dignity. Section 7.1 recognises human dignity as a core value of the Constitution, which means that it is used as a Grundnorm or regulative ideal in adjudicating conflicts between the various fundamental rights circumscribed in the Bills of Rights. When fundamental rights clash with each other, the following question is asked: how closely does a specific right relate to human dignity? In other words, what is the harm caused to a person's dignity? This means that the harm principle when applied is automatically expanded to the realm of dignitary harms. This state of affairs is unproblematic in cases where dignitary harms are clearly measurable. For example, during the Covid-19 crisis, the right to freedom of movement entered into conflict with the right to life. The more people moved, the easier the virus spread. Emergency regulations resolved the conflict by consistently upholding the right to life at the expense of freedom of movement. Right to life is after all much more closely related to dignity than freedom of movement. In this case, harm to dignity served as an unproblematic criterion in determining whether a right should be limited. 
However, things become much more complicated when it comes to issues such as psychological harm. In contrast to most other jurisdictions, South African common law employs the concept of crimen injuria, which is defined as 'an act which intentionally impairs the dignity or privacy of another'. The South African Prevention and Combating of Hate Crimes and Hate Speech Bill (2018) correspondingly prohibits hate speech, based on 17 features ranging from race- and culture-specific characteristics to sexual orientation. Clause 4 (i), moreover, stipulates the intention to be harmful or to incite harm as a fundamental feature of hate speech. ${ }^{1}$

The act's expansion of the harm principle to the sphere of dignity is understandable in the light of South-Africa's repressive and racist past, but the unintended consequence is that too wide a range of social actions can be scrutinised under the harm principle. The state apparatus possesses considerable leeway to interfere in the private sphere of life under the guise of the harm principle. In the United States of America, dignitary harms caused by religious speech have generally been trumped by the priority given to first amendment rights (Barclay 220:368), but freedom does not enjoy the same priority in the South African context. Whilst rights related to human dignity and equality are described by the Constitution as 'nonderogable', many freedoms, including religious freedom, are not part of the list (section 37). It is, therefore, not surprising to see the gradual erosion of religious freedom in South Africa. Even as South African courts and laws have shown commitment to protect the autonomy of religious institutions, signs are on the increase for the 'erosion of religious autonomy in various fields' according to Van Coller (2020:220). She cites the extension of aspects of labour law to religious employees, the requirement of the Civil Union Amendment Bill that marriage officers who are civil servants may no longer object on conscientious grounds to solemnising same-sex civil unions and recommendations by the South African Revenue Service that the taxation of religious institutions should be considered (Van Coller 2020:220). The actions of the CRL Commission exhibit the most intrusive effort thus far to limit religious rights. Notwithstanding these developments, my concern is not that religious freedom in South Africa is currently under threat, but that conceptual tools exist that are open to abuse. In future, governments hostile to religion may use these tools to restrict religious rights.

\section{Conclusion}

Up to the present, religious freedom has enjoyed significant constitutional and legal protection in South Africa. However, it is becoming increasingly clear that rogue pastors, charlatans and religious cults have been exploiting the constitutional space provided for religions to serve ulterior purposes. The CRL Commission attempted to address these issues through draconic measures, but they are unlikely to succeed, as their

1.Section $4(2)(d)$ of the particular act contains a religious exemption clause that states that religious speech done in good faith and based on bona fide interpretations of that religious spections of religious tenets will not be regarded as hate speech, provided they do not incite to cause harm. This indicates that lawmakers envisaged the problematic consequences that crimen injuria legislation could have for religious speech. However, this exemption clause does not resolve the possibility for misuse of the harm principle in other spheres of life. recommendations do not satisfy the conditions of section 36 (e) of the Constitution, which requires that 'less restrictive means can be used to achieve the same purposes'.

The basic intuition of the Commission, namely, that the ambit of religious freedom is overly extensive, and that it needs to be narrowed down, is not without merit. The narrowing down process has in fact already begun, as evidenced by the number of legal challenges lodged against religious practises, such as religious prayers at schools, religious discrimination against homosexual ministers and employees and so forth. Going forward, it is important to use efficient and reasonable tools to adjudicate when and how religious rights should be limited. It is of utmost importance that religious communities themselves must have a say in the process of determining the ambit of religious freedom. In fact, former Constitutional Justice Albie Sachs (1990:46-47) proposed way back in 1990 that South African people of religion should come together and draft a charter of religious rights because it is ultimately up to religious people themselves to define their fundamental rights. This proposal has indeed been followed up. A South African Charter of religious rights and freedoms was signed by almost every major religious groups on 21 October 2010, but the Charter had not as yet been adopted by Parliament in terms of section 234 of the Constitution (see Benson 2011:125-134). Whilst the document does not address the harm principle directly, it provides a very clear framework for dealing with issues related to institutional autonomy, physical endangerment and religious exploitation, and hence serves as a promising foundation for future engagements between the CRL and religious groups. When it comes to considering the limitation of rights, harm will always be an important element. But it cannot fulfil the central role that some ascribe to it. The harm principle, I submit, is deeply flawed because of its fluid and ambiguous nature, which invites a wide range of rival interpretations, its non-categorical nature, which makes the general application of rules difficult and its vulnerability to abuse within a South African context.

\section{Acknowledgements Competing interests}

The author declares that he has no financial or personal relationships that may have inappropriately influenced him in writing this article.

\section{Authors' contributions}

$\mathrm{NV}$ is the sole author of this research article.

\section{Ethical considerations}

This article followed all ethical standards for research without direct contact with human or animal subjects.

\section{Funding information}

This research received no specific grant from any funding agency in the public, commercial or not-for-profit sectors. 


\section{Data availability}

Data sharing is not applicable to this article as no new data were created or analysed in this study.

\section{Disclaimer}

The views and opinions expressed in this article are those of the author and do not necessarily reflect the official policy or position of any affiliated agency of the author.

\section{References}

Banda, C., 2019, 'Redefining religion? A critical Christian reflection on CRL Rights Commission's proposal to regulate religion in South Africa', Verbum et Ecclesia 40(1), a9148. https://doi.org/10/4102/ve.v40i1.1948

Barclay, S., 2020, 'First amendment harms', Indiana Law Journal 95(1), 331-390.

Benson, I.T., 2011, 'South African charter of religious rights and freedoms. Constitutional framework, formation and challenges', International Journal of Religious Freedom 4(1), 225-234.

Church Leaders Empowerment Foundation of South Africa (CLEFA), 2017 Submission to the Parliaments of South Africa, pp. 1-3, viewed 16 November 2020, from https://static.pmg.org.za/.

CRL Rights Commission, 2016, Preliminary report of the hearings on commercialization of religion and abuse of people's belief systems, pp. 1-50, viewed 16 November 2020, from https://synapses.co.za/uploads/CRLReport.pdf.

CRL Rights Commission, 2017, Report of the hearings on commercialization of religion and abuse of people's belief systems, pp. 1-33, viewed 16 November 2020, from https://www.crlcommission.org.za/publications.

Dripps, D.A., 1998, 'The liberal critique of the harm principle', Criminal Justice Ethics 17(2), 3-18. https://doi.org/10.1080/0731129X.1998.9992054
Du Plessis, G., 2016, 'The legitimacy of using the harm principle in cases of religious freedom within education', Human Rights Review 17, 349-370. https://doi. org/10.1007/s12142-016-0415-5

Epstein, R.A., 1995, 'The harm principle - And how it grew', The University of Toronto Law Journal 45(4), 369-417. https://doi.org/10.2307/825731

Feinberg, J., 1986, Harm to others, Oxford University Press, Oxford.

Freedom of Religion South Africa (FOR SA) \& South African Council for the Protection and Promotion of Religious Rights and Freedoms (SACRRF), 2017, Comments on the CRL Commissions report on the commercialisation of religion, viewed 16 November 2020, from https://static.pmg.org.za/171017SARRF.pdf.

Holtug, N., 2002, 'The harm principle', Ethical Theory and Moral Practise 5, 357-389. https://doi.org/10.1023/A:1021328520077

International Institute for Religious Freedom, 2017, Argument regarding the CRL Rights Commission's Final Report on the "commercialisation" of religion and abuse of people's belief systems, pp. 1-8, viewed 16 November 2020, from https://static.pmg.org.za/171017IIRF.pdf.

Maviya, L., 2018, 'The case for regulating religion', Mail \& Guardian, 29 March.

Mill, J.S., 1863, On liberty, Ticknor and Fields, Boston, MA.

Republic of South Africa, 2018, Prevention and combating of hate crimes and hate speech bill, Author, Minister of Justice and Correctional Services, Cape Town.

Ripstein, A., 2006, 'Beyond the harm principle', Philosophy \& Public Affairs 34(3), 215-245. https://doi.org/10.1111/j.1088-4963.2006.00066.x

South African Law Reform Commission, 2014, Media Statement by the South African Law Reform Commission, viewed 29 March 2021, from 20160119-prj135-dp139WitchcraftSuppression.pdf (justice.gov.za).

Sachs, A., 1990, Protecting human rights in a new South African. Contemporary South African debates, Oxford University Press, London.

Van Coller, H., 2020, Regulating religion. State governance of religious institutions in South Africa, ICLARS series on law and religion, Routledge, London.

\section{Court Cases}

$R v$ Malmo-Levine; $R v$ Caine [2003] 3 S.C.R. 571, 2003 SCC 74. 